\title{
Viselkedésgazdaságtan a fogyasztóvédelemben
}

\author{
Berki-Süle Margit' - Hlédik Erika² \\ 'Budapesti Müszaki és Gazdaságtudományi Egyetem \\ 2Eötvös Loránd Tudományegyetem
}

\begin{abstract}
A TANULMÁNY CÉLJA
A fogyasztói döntések tisztességtelen befolyásolásának felismerése, és az ehhez kapcsolódó fogyasztóvédelmi szabályozás meghatározó a fogyasztói magatartás vizsgálata szempontjából. Az elmúlt évtizedekben a viselkedési közgazdaságtan kutatási eredményei a fogyasztóvédelmi politika alakításában is jelentős szerepet játszanak. Tanulmányunkban azt vizsgáljuk, hogy a viselkedésgazdaságtani kutatások eredményei hogyan alkalmazhatóak a fogyasztóvédelem gyakorlatában.
\end{abstract}

\begin{abstract}
ALKALMAZOTT MÓDSZERTAN
A Gazdasági Versenyhivatal döntései közül három termékkörhöz kapcsolódóan konkrét esettanulmányok feldolgozásával az egyes döntési heurisztikák megjelenésére mutatunk be példát és azt vizsgáljuk, hogy ezeket a döntési hibákat fel- és kihasználó tisztességtelen marketingkommunikációs gyakorlatokat miként ítélte meg a hatóság, és hogyan hatottak a szabályozásra.
\end{abstract}

\section{LEGFONTOSABB EREDMÉNYEK}

A vizsgált termékköröket érintően azonosíthatóak voltak olyan döntéshozatali hibák kihasználását lehetővé tevő kereskedelmi gyakorlatok, különösen a termékek vásárlási döntés szempontjából fontos tulajdonságainak, ezzel kapcsolatos információk mennyiségére, átadási módjára és formájára vonatkozóan, amelyek során a vállalkozások részben az adott területre jellemző alul- vagy túlszabályozottsága miatt megfelelési törekvéseik ellenére sem tudtak megfelelö körültekintéssel eljárni.

\section{GYAKORLATI / GAZDASÁGPOLITIKAI JAVASLATOK}

Az eljárás alá vont vállalkozások álláspontja, valamint a versenytanácsi döntések és azok háttere elemzésének összefoglalásaként megállapítható, hogy a fogyasztóvédelmi jogalkotási és -alkalmazási gyakorlatban közvetetten és közvetlen módon (az érintett fogyasztói kör jellemző magatartásának leírásában) is megjelennek a viselkedési közgazdaságtan által feltárt és a kilátáselméletben összefoglalt, racionálistól eltérő fogyasztói magatartásminták. Így ezek megfelelő alapot jelenthetnek nem csak a jogalkalmazás, hanem a jogalkotás számára is. Az elemzésünkkel szeretnénk felhívni a figyelmet a fogyasztóvédelmi szabályozás témakörének fontosságára a marketingoktatásban is. Úgy gondoljuk a bemutatott esetek elemzése a gyakorló marketing szakemberek számára is hasznos adalékként szolgálhatnak. A vállalati oldal számára kulcsfontosságú a szabályozás alapos ismerete, másfelöl a keresleti oldalon a fogyasztóvédelmi ismeretek segítenek jobb döntéseket hozni.

Kulcsszavak: viselkedési közgazdaságtan, fogyasztói döntés, fogyasztóvédelem, tisztességtelen gyakorlat DOI: https://doi.org/10.15170/MM.2019.53.EMOK.01 


\section{BEVEZETÉS}

A fogyasztói döntések tisztességtelen befolyásolása, és az ehhez kapcsolódó fogyasztóvédelmi szabályozás meghatározó a fogyasztói magatartás vizsgálata szempontjából. A fogyasztóvédelemi megközelítés érdekes kérdéseket vet fel a fogyasztói döntések folyamatának feltárása, valamint a vállalatok kommunikációs tevékenységének kialakítása és értékelése során. Egyrészt kétség nélkül kijelenthető, hogy a vállalatok számára kulcsfontosságú a szabályozás ismerete, másfelöl a keresleti oldalon a fogyasztóvédelmi ismeretek a kritikus fogyasztói szemlélet és értékrend kialakulásához is hozzájárulnak.

A Gazdasági Versenyhivatal által követett, a fogyasztói döntések szabadságára vonatkozó alapelveket feltáró és magyarázó dokumentum (GVH 2009) szerint a piaci verseny célja a hosszútávú fogyasztói jólét, a versenyképesség és a hatékonyság, amely elösegíti a gazdasági növekedést, a foglalkoztatást, és az életszínvonal emelkedését. A GVH állásfoglalása szerint a verseny egyben a fogyasztói érdekek védelmének hatékony eszköze is, amelyben a fogyasztói döntések szabadsága hozzájárul a verseny hatásosságához. A fogyasztói döntés nem tekinthető szabadnak, ha az információkeresési folyamatot egy vállalkozás tisztességtelenül befolyásolja. A fogyasztói döntés szabadsága alapvetően két esetben szenvedhet csorbát:

1. megtévesztő tájékoztatás esetén, ha olyan elemek szerepelnek a vállalat marketingstratégiájában, amelyek nem fedik a teljes valóságot a termékről vagy a vállalatról,

2. a fogyasztói döntési folyamatba való közvetlen beavatkozás által, egyes agresszív kereskedelmi gyakorlatok alkalmazása azt a látszatot kelheti a fogyasztó számára, hogy rendkívül alacsony keresési költséggel hozhatja meg a termékre vonatkozó döntését.

Fletcher (2008), az angol verseny- és fogyasztóvédelmi hatóság, az Office of Fair Trading vezető közgazdásza szerint a fogyasztóvédelmi politika célja egyrészt a fogyasztók aktivizálása, hogy ,jó" döntéseket hozva segítsék a piac hatékony múködését, másodsorban - a hagyományos szemléletnek megfelelöen - a fogyasztók védelme a piac müködésének árnyoldalaival szemben, harmadrészt pedig a fogyasztói bizalom növelése, amely keresletnövelö hatású. A fő kérdés azonban az, hogy miként érhetők el ezek a törekvések a leghatékonyabb módon. Fletcher (2008) úgy véli, a viselkedési közgazdaságtan megközelítései hatékony segítséget nyújthatnak a fogyasztóvédelmi politika fejlesztésében.
Tanulmányunkban azt vizsgáljuk, hogy a viselkedésgazdaságtani kutatások eredményei hogyan alkalmazhatóak a fogyasztóvédelem gyakorlatában. Először áttekintjük azokat a viselkedési közgazdaságtani megközelítéseket, amelyekröl úgy véljük, leginkább alkalmazhatóak a fogyasztóvédelem területén, vagy már alkalmazzák is őket. Ezután a Gazdasági Versenyhivatal döntései közül konkrét esettanulmányok bemutatásával az egyes döntési heurisztikák megjelenésére mutatunk be példát és azt vizsgáljuk, hogy milyen hibákat követtek el vállalkozások marketingkommunikációjuk során, és ezek hogyan hatottak a szabályozásra. Fontosnak tartjuk hangsúlyozni, hogy alapvetően ezekkel a döntési heurisztikákra építő technikákkal (mint például a keretezés) való tisztességtelen visszaélés vezet(het) döntési hibához, amit a fogyasztóvédelemnek szankcionálnia kell, nem önmagukban ezeknek a használata. Az elemzésünkkel szeretnénk felhívni a figyelmet a fogyasztóvédelmi szabályozás témakörének fontosságára a marketingoktatásban. Úgy gondoljuk, a bemutatott esetek elemzése a gyakorló marketing szakemberek számára is hasznos adalékként szolgálhat.

\section{SZAKIRODALMI ÁTTEKINTÉS}

Elemzésünk kiindulópontja az állam - a fogyasztóról, illetve a fogyasztó piaci viselkedéséről vallott nézetek által determinált - gazdaságban betöltött szerepének vizsgálata, amely eltérő hangsúlyt kapott a XIX. század gazdaságpolitikájában, a jóléti közgazdaságtani, majd a fogyasztói gazdaságelméletben. A klasszikus közgazdasági alapfeltevés szerint, amely egyben a neoklasszikus közgazdaságtan alapvetése is, a gazdaság alapszereplöi, a fogyasztók minden egyes árucikknek, illetve szolgáltatásnak ismerik a számukra való hasznosságát, és fogyasztói döntéseiket az vezeti, hogy a rendelkezésükre álló bevételek alapján maximalizálják a várható hasznosságot (Bernoulli 1954 [1738], Neumann \& Morgenstern 1947). Kahneman és Tversky (1979) más irányt választottak és pszichológiai értelmezést (elméletet) kerestek az emberek döntéseinek leírására, saját kísérleteket dolgoztak ki és folytattak le elméletük, a kilátáselmélet (prospect theory) igazolására (Kahneman 2013).

A viselkedési közgazdaságtan (a döntéselmélet) által feltárt jelenségeket, a fogyasztói döntések anomáliáit és ezek magyarázatát nemcsak a marketing kamatoztathatja (illetve kamatoztatta elsőként). Thaler és Sunstein (2011 [2008]) amellett érvelnek, hogy a döntéseinkben rejlő „hibák” a saját javunkra 
fordíthatók, ha a kormányzatok mintegy „döntéstervezőként" úgy formálják (csomagolják) a döntési helyzeteket, hogy azok jobb döntésre késztessék az állampolgárokat, fogyasztókat (lásd ,Az mpg-illúzió” Larrick \& Soll [2008] kutatásaiban, a „Save More Tomorrow” vagy a „MyPlate” programok).

A hagyományos, paternalista szemlétü fogyasztóvédelem feladata az alárendelt és kiszolgáltatott fogyasztó, mint a szabadpiac visszaélései passzív áldozatának védelme szigorú jogi eszközökkel és eröteljes állami beavatkozással a magánjogi jogviszonyokba. Ezzel szemben Thaler \& Sunstein (2011 [2008]) libertárius (libertariánus) paternalizmus elméletének alapgondolata, hogy az egyre komplexebbé váló világban (különösen a pénzügyi válság éveiben) a fogyasztók érdekeit nem az egyre erősödő hagyományos paternalista szemléletü (fogyasztó)védelemmel lehet leginkább szolgálni. Érvelésük szerint a fogyasztóvédelmi szabályozás az alapvető célját a választási lehetőségek korlátozása helyett, - a viselkedési közgazdaságtan eredményeire építve - a fogyasztói döntések befolyásolásával, a fogyasztók „ösztökélésével” („,nudge”) érheti el.

$\mathrm{Az}$ aszimmetrikus paternalizmus alapgondolata szerint, amennyiben a szabályozó különbséget tud tenni a fogyasztók csoportjai között (például a kiszolgáltatott fogyasztói csoportok megkülönböztetése révén), akkor olyan szabályozási mechanizmus is kialakítható, amely nagy haszonnal jár azoknak, akik döntési hibákat követnek el, de kis terhet jelent vagy nem árt azoknak, akik teljesen racionálisak. Camerer és szerzőtársai (2003) a fogyasztók differenciálásából indulnak ki; vannak fogyasztók, akik képesek a neoklasszikus közgazdaságtan „homo oeconomicus” modelljének megfelelö racionális döntést hozni (Thaler - Sunstein 2011 [2008], ,ekonok”), és olyanok is, akik korlátozottan racionálisak, döntési heurisztikákat alkalmaznak (Thaler - Sunstein 2011 [2008], „humánok”). A szerzők a fogyasztóvédelmi vonatkozások kapcsán a fogyasztói hitelekkel, a jelzálogkölcsönökkel és a gépjármű lízingszerződésekkel kapcsolatos tájékoztatási kötelezettségeket említik, mint az aszimmetrikus paternalizmus hatékony megvalósulási formáit a szabályozásban.

A fogyasztói döntéshozatal hibáiról alkotott elméletek megváltoztathatják (illetve, ahogy látni fogjuk, ez a folyamat már elindult) a helyes fogyasztóvédelmi szabályozásról alkotott képet. Ez a felismerés az Európai Uniót is arra sarkallta, hogy az Európai Bizottság fogyasztóvédelemért felelős föigazgatóságán (DG SANCO) belül felállítson egy, a fogyasztói viselkedést kutató egységet. A kutatókból álló szervezet tevékenységének köszönhetően a fogyasztóvédelmi politika viselkedéstudományi kutatások eredményein alapuló intézkedései között említhető meg a 2011. évi (hazánkban 2014 júniusában a fogyasztók és a vállalkozások közötti szerzödések részletes szabályairól szóló 45/2014 (II.26.) Korm. rendelet elfogadásával hatályba lépő), a fogyasztók jogairól szóló 2011/83/EU irányelv extra vagy kiegészítő szolgáltatásokra vonatkozó pontja, a jellemzően az online kereskedelemben alkalmazott elöre bejelölt (ún. pre-checked) opciók tilalma, valamint egy, a beavatkozások hatékonyságának viselkedéstudományi kutatásokon alapuló ex-ante felmérésére szolgáló eljárás kialakítása (lásd Van Bavel et al. 2013).

Fletcher (2008) a fogyasztó döntési folyamatához kapcsolódóan az egyes viselkedési torzítások, hibák fogyasztóvédelmi szabályozására tett javaslatot (lásd 1. ábra). Az információszerzési fázis során a referenciaponthoz való ragaszkodás, a limitált figyelem jelensége, illetve a reprezentativitási elóítélet kapcsolódik leginkább. Ebben az esetben a fogyasztóvédelem feladata az átláthatóság javítása, amely a tisztességtelen kereskedelmi gyakorlatok tilalma és szabályozása révén valósulhat meg. Az információk értékelése során a keretezés, a túlzott magabiztosság és a horgonyzás jelensége viheti tévútra a fogyasztót. Ezért szükséges a fogyasztó támogatása az információk feldolgozásában, amelyet többek között a szerzödések tartalmának egyoldalú, a fogyasztó hátrányára történő megállapításának tilalma szolgál. A legnehezebb feladat a fogyasztó helyes döntésének (cselekvésének vagy épp nem cselekvésének) a támogatása. Ebben az esetben a szabályozás csak egyfajta biztosítékot tud nyújtani a fogyasztói döntés utólagos kontrolljához, mint például a távollévők közötti kereskedelemben megjelenö többletjog, az elállás joga. A fogyasztóvédelmi gyakorlatban megjelenő és az általunk a későbbiekben bemutatott esetek leginkább a fogyasztói döntés befolyásolására alkalmas kereskedelmi gyakorlatok, vagyis a szükséges információk megszerzésének (észlelésének) és feldolgozásának manipulálásához köthetők. 


\section{1. ábra: A fogyasztó(védelm)i politika eszközei a fogyasztói döntéshozatalt befolyásoló viselkedési torzítások hatásának csökkentésére}

Fogyasztói

döntés

Viselkedési hibák /

torzítások

Fogyasztó(védelm)i politika feladata

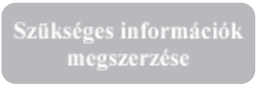

Referenciafüggőség

Limitált figyelem

Reprezentativitási

előítélet

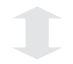

$\mathrm{Az}$ átláthatóság javítása

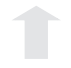

Tisztességtelen keres-

kedelmi gyakorlatok

tilalma

Fogyasztó(védelm)i

politika eszközei

\section{Adatszolgáltatás \\ szabályozása}

(Ár-összehasonlítás)

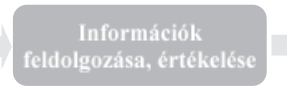

Túlzott magabiztosság

\section{Keretezés}

Beakaszkodás

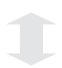

Az információfeldolgozás segítése

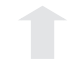

Elállás joga

Tisztességtelen szerződési feltételek tilalma

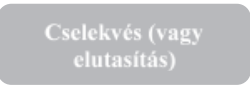

Referenciafüggőség

Önkontroll-problémák

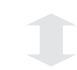

Döntés / cselekvés

támogatása

Elállás joga

Forrás: Fletcher 2008 alapján saját szerkesztés

A fogyasztói racionalitás és a versenyszabályozás kapcsolatával, a kilátáselmélet fogyasztóvédelmi és versenyjogi vonatkozásaival foglalkozott továbbá Koltay és Vincze (2009), Fekete (2006) és Süle (2017), akik a racionálistól eltérő magatartásminták bemutatásán túlmenően példákon keresztül érzékeltették azok megjelenését a hazai versenyjogi gyakorlatban (nemzetközi példákat lásd az OECD [2017] jelentésében).

A kutatásunk alapja - a 2005/29/EK irányelv (röv. UCPD) maximum harmonizációjával hozott - 2008. évi XLVII., a fogyasztókkal szembeni tisztességtelen kereskedelmi gyakorlat tilalmáról szóló törvény (röv. Fttv.), amelyben indirekt módon kerültek meghatározásra a fogyasztók tájékoztatásával kapcsolatos minimumszabályok, a kereskedelmi gyakorlatok tilalmazott formái (megtévesztô tevékenység vagy mulasztás, agresszív kereskedelmi gyakorlat, lásd. 1. táblázat). A hivatkozott törvény a fogyasztói döntési folyamat egészét kívánja védeni az üzleti vállalkozásoknak a termékhez kapcsolódó kereskedelmi ügylet lebonyolítását megelőzően és azt követően, valamint a lebonyolítás során alkalmazott kereskedelmi gyakorlatának szabályozása révén. A kereskedelmi gyakorlatok megítélésénél a hatóságok ennek megfelelően több szempont - az értékesítés, kommunikáció körülményeinek, az áru jellegének, a fogyasztói döntés teljes folyamatának, a fogyasztók adott szituációban jellemző magatartásának - figyelembevételével mérlegelnek és az érintettek meghallgatásával - esetleges enyhítö körülmények értékelésével - hoznak döntést. Az eljárások központi eleme a vállalkozások információ-kezelésének - a fogyasztók részére nyújtott információ tartalmának, mennyiségének és az információ-átadás formájának - vizsgálata aszerint, hogy az megfelelő alapot jelentett-e a fogyasztók számára a szabad vásárlási döntés meghozatalára. 


\section{1. táblázat: Az Fttv. (2008. évi XLVII. törvény) szerkezeti felépítése}

\begin{tabular}{|c|c|c|c|c|}
\hline \multicolumn{5}{|c|}{ Generálklauzula (3. § (1) bekezdés) } \\
\hline \multicolumn{4}{|c|}{ Megtévesztő kereskedelmi gyakorlat } & \multirow{3}{*}{$\begin{array}{c}\text { Agresszív } \\
\text { kereskedelmi } \\
\text { gyakorlat }(8 . \S)\end{array}$} \\
\hline \multicolumn{2}{|c|}{$\begin{array}{l}\text { Megtévesztő tevékenység } \\
\text { (aktív megtévesztés) }(6 . \S)\end{array}$} & \multirow{2}{*}{\multicolumn{2}{|c|}{$\begin{array}{c}\text { Megtévesztő mulasztás } \\
\text { (passzív megtévesztés) (7. §) }\end{array}$}} & \\
\hline $\begin{array}{c}\text { valótlan tény } \\
\text { állítása }(6 . \S(1) \\
\text { bekezdésének első } \\
\text { fele) }\end{array}$ & $\begin{array}{l}\text { valós tény megté- } \\
\text { vesztésre alkalmas } \\
\text { módon való állítása } \\
\text { (6. } §(1) \text { bekezdésé- } \\
\text { nek második fele) }\end{array}$ & & & \\
\hline \multicolumn{5}{|c|}{ Feketelista (Melléklet) } \\
\hline \multicolumn{3}{|c|}{$\begin{array}{c}\text { Megtévesztő kereskedelmi gyakorlatok } \\
\text { (1-23. pontok) }\end{array}$} & \multicolumn{2}{|c|}{$\begin{array}{c}\text { Agresszív kereskedelmi gyakorlatok } \\
\text { (24-31. pontok) }\end{array}$} \\
\hline
\end{tabular}

Forrás: Balogh 2010 és a 2008. évi XLVII. törvény alapján saját szerkesztés

\section{ESETPÉLDÁK}

Tanulmányunkban három termékkör kapcsán hozott GVH döntéseket mutatunk be, amelyeknek valamilyen viselkedési közgazdaságtani vonatkozása van. $\mathrm{Az}$ esetek bemutatásakor törekedtünk arra, hogy bemutassuk a fogyasztói döntést torzító jelenségeket, és olyan konkrét eseteket, amikor ezeket alkalmazva a vállalat kommunikációs tevékenysége megtévesztő volt. Az esetek kiválasztásához a GVH versenyhivatali döntéseit vettük alapul. Az esetek bemutatásakor először az adott befolyásoló, torzító jelenséget mutatjuk be, majd a konkrét kereskedelmi gyakorlatot, amely során a vállalat ezt a torzítást félreérthetően használta, végül a kommunikáció során elkövetett hibák fogyasztóvédelmi szabályozását ismertetjük.

\section{Keretezési hatás}

Az egyik legtöbbet hivatkozott csomagolási vagy keretezési hatás (framing effect) lényege, hogy egy bizonytalan döntési helyzetben jelentősen felértékelödik annak a szerepe, hogy milyen módon és formában tálalják a fogyasztónak az adott problémát (terméket vagy szolgáltatást). Keretezési hatást válthatnak ki a döntést megelőzően a tájékoztatás során nyújtott információk mennyiségében mutatkozó különbségek, a döntést befolyásoló információk előadásának módja vagy az opciók száma, amelyeket a fogyasztónak felkínálnak (Hámori 2003). A keretezési hatás piaci megjelenésének tipikus esetei a kiemelések, különböző színek és betüméretek (apró betűs szövegek) alkalmazása a tájékoztatás során, amelyek kapcsán a legjelentősebb vitapont a fogyasztó számára való észlelhetöségük és a megjelenített üzenet értelmezhetősége.

Probléma: A keretezési hatás félrevezető alkalmazására volt példa a termékek magyar eredetére vonatkozó utalás a termékek csomagolásán és/ vagy a reklámokban. A vállalkozások felismerve a hazai fogyasztók magyar termékekhez füződő fogyasztási attitüdjét, információs hiányosságait és esetleges döntési hibáit, ,automatikus reakcióként” mindinkább felhívták a fogyasztók figyelmét az általuk gyártott vagy forgalmazott termékek (valós vagy tulajdonított) magyar voltára. Egyre többször jelent meg a különböző élelmiszeráruház-láncok reklámújságaiban, eladáshelyi reklámjaiban, valamint köztéri reklámhordozókon és a nyomtatott sajtóban a „magyar" jelző (,magyar minőség”, „Magyar Értéket Örzünk”, „Auchan Hungarikum"), valamint az erre utaló nemzeti színek és motívumok. A hatóság megítélése szerint, ,ilyen termékmegjelölés egy elözetesen rögzitett, az egész vállalkozásra kiterjedö és következetesen alkalmazott követelményrendszer alapján alkalmazható", valamint az élelmiszerek esetén elvárás, hogy ezeket „a követelményeket legalább a termék gyártási / származási helyére, illetve alapanyagainak eredetére figyelemmel alakitsák ki" (GVH 2011:2), így a vállalkozások azzal, hogy egy egységes követelményrendszer nélkül magyar jelleget hangsúlyozó termékmegjelöléseket használtak, jogsértést követettek el.

A Versenytanács a termékek magyarként való megtévesztő reklámozása kapcsán a keretezési 
hatásra utalóan kifejtette, hogy a reklámelemek sorrendiségét illetően nem fogadható el az eljárás alá vontnak a szlogen szövegének tartalmát előtérbe helyező álláspontja: „Közismert a reklámban a szinek orientáló, figyelemfelkeltö hatása. A szin közvetlenül hatol tudatunkba, a szavak pedig csak hosszas kerülövel. A szineket nem kell konkrét nyelvre forditani, azon mód megérthetök." (Vj-017/2011). Az összetett (színt, ábrát és szöveget is használó) reklámüzenet észlelési sorrendje tehát éppen fordított, mint ahogy azt az eljárás alá vont vállalkozás az adott ügyben kifejti. Ez az észlelési sorrend kizárja azt, hogy a fogyasztó hosszasan elgondolkodjon a szlogen tartalmának jelentésén, és csak ezt követően értékelje a színeket és az ábrákat, és azokat ne eredeti jelentéstartalmuk szerint, hanem a szlogenben szereplő ,hungarikum” kifejezéssel összhangban álló tartalommal értelmezze. A hivatkozott eset, valamint a témakörrel kapcsolatos tanulmányok (Malota 2011, Miskolczi Bodnár 2011, GVH 2012) fókuszában akkor még külön szabályozás híján a „magyar termék” mibenlétének és a „magyar” jelző fogyasztási döntést befolyásoló hatásának vizsgálata állt.

Az esetek kapcsán a legfőbb problémát annak megítélése jelentette, hogy a kereskedelmi gyakorlat által megszólított fogyasztók értelmezése szerint milyen tartalommal bír az érintett áruk esetén alkalmazott „magyar termék” állítás, vagyis, hogy mit tekinthetünk magyarnak. Ebben a kérdésben a Versenytanács korábbi, konzekvens és a bírói gyakorlat által is megerősített döntéseire, valamint a hazai fogyasztók körében végzett közvélemény-kutatások eredményeire támaszkodhatott. A kérdésben megoldást a 2012-ben elfogadott $a z$ egyes önkéntes megkülönböztetö megjelölések élelmiszereken történö használatáról szóló 74/2012. (VII.25.) VM rendelet hozott, amelyben meghatározásra került, hogy pontosan milyen feltételek érvényesülése esetén mondható egy termék (élelmiszer) „magyarnak” és bármilyen ezzel egyenértékű állítást (például szó, szókapcsolat, kép vagy grafikai megjelenítés), jelölést, megkülönböztető információt csak akkor használhatnak, ha ezeknek a feltételeknek az eladásra szánt élelmiszer megfelel.

\section{Felidézési elöitélet}

A felidézési elöitélet (availability bias) szerint az emberek hajlamosak nagyobb gyakoriságot tulajdonítani azoknak az eseményeknek, amelyek az átlagosnál intenzívebb érzelmi vagy érzékelésbeli hatást gyakoroltak rájuk. Ezt kihasználva a fogyasztók gyakran ,érzéki csalódás” áldozataivá válnak, de erre építenek az erőszakos, tragikus vagy szexuális elemeket tartalmazó reklámok, valamint ide sorolhatók még azok a reklámok is, amelyek a személyes érintettségből fakadó kiszolgáltatottságot használják ki (Fekete 2006).

A tisztességtelen kereskedelmi gyakorlatok kapcsán is kitüntetett figyelmet érdemel a - GVH határozatai között 2008-2013 között legnagyobb számban megjelenő - gyógyhatású és emberi egészségre ható készítményekkel (gyógyszerekkel, gyógyszernek nem minősülő gyógyhatású készítményekkel, gyógynövény készítményekkel és élelmiszerekkel, étrend-kiegészítőkkel) kapcsolatos tájékoztatás. Ezeknél a termékeknél fokozottabban érvényesül az információs aszimmetria jelensége, hiszen a fogyasztók ritkán rendelkeznek megfelelő ismeretekkel az egyes gyógyhatású készítmények hatásairól.

Probléma: Olyan gyógyhatás tulajdonítása a reklámozott terméknek, amely nem megfelelően alátámasztott. A reklám azt sugallta, hogy a termék hatékonyan kezeli többek között a lábfej, a térd, a csípő, a derék és a váll ízületi megbetegedéseit. A felidézési előítélet jelenség abban mutatkozik meg, hogy a reklám során betegek és orvosok nyilatkoztak a szer hatásosságáról.

Amennyiben egy állítás gyógyhatásra vonatkozik úgy az Fttv. mellékletének 17. pontja körében értékelendö, amely szerint minden körülmények között tisztességtelennek minősülő gyakorlat ,,annak valótlan állitása, hogy a termék alkalmas betegségek, illetve az emberi szervezet müködési zavarainak vagy rendellenességeinek gyógyitására". A gyógyhatású vagy az egészségi állapot javítására szolgáló termékek vásárlóit (tipikusan időseket, betegeket, fogyatékosokat) a fogyasztóvédelmi joggyakorlat különösen veszélyeztetett és sérülékeny fogyasztói csoportként kezeli, akik a gyógyulás vagy gyógyító hatás reményében lényegesen érzékenyebben reagálnak az ezt ígérő tájékoztatásra és anyagi erejüket meghaladó kiadásokra is hajlandók. Ezért az esetek megítélése kapcsán figyelembe kell venni, hogy e célcsoport tagjaitól kiszolgáltatottságuk miatt fogyasztási döntéseik során alacsonyabb ésszerüségi szint várható el, mint egy ,átlagfogyasztótól”, valamint kellő szakmai tudás hiányában elsősorban a reklámok ígéreteire tudnak támaszkodni a piacon problémájukra kínált termékek közötti választásban (Ottlakán 2012). E termékkörök kapcsán éppen ezért kiemelt jelentősége van a fogyasztók „,tényszerü, túlzásokat nélkülözö, korrekt, az ágazati szabályoknak is megfelelö, valós és ténylegesen, szakmailag bizonyitott állitásokat tartalmazó tájékoztatásnak" (Vj-019/2013). A termékek gyógyhatására vonatkozóan a legszi- 
gorúbb e kitétel, miszerint az állítások valóságnak való megfelelését a vállalkozásnak tudományos ismeretekkel kell igazolnia, és e vonatkozásban a betegektől vagy kezelőorvosoktól származó vélemények, illetve pozitív terméktapasztalatok nem tekinthetők annak. A termékeknek igazolatlanul gyógy- és egészségre jótékony hatást tulajdonító állítások kapcsán a Versenytanács továbbá kiemeli, hogy az üzenet-közvetítés eredményessége a fentiekre tekintettel - részben érzelmi, részben értelmi alapú. A fogyasztókat érzelmileg befolyásolhatja, hogy (tipikusan televíziós vásárlási müsorablakokban) sorstársak beszámolóit láthatják, hallhatják, esetenként szakemberek megerősítésével.

\section{Reprezentativitási elöitélet}

A reprezentativitási elöitélet (representativeness bias) szerint az emberek aránytalanul eltérően érzékelik a különböző időpontbeli valószínűségeket; nagyobb valószínűséget (s így jelentőséget) tulajdonítanak az időben közelebb bekövetkezö eseményeknek, míg a korábbiaknak vagy későbbieknek kisebbet, függetlenül azok tényleges bekövetkezési valószínűségétől. Az Fttv. törvény elfogadását követő két évben az elmarasztaló eljárások közel fele pénzügyi szolgáltatásokat nyújtó, illetve fogyasztói csoportokat szervező vállalkozások ellen indult.

Probléma: A fogyasztói csoportok reklámjaiban nem adtak egyértelmú információt a fogyasztói csoportok lényeges tulajdonságairól, például arról, hogy a fogyasztói csoport tagjai nem pénzhez, hanem vásárlói joghoz jutnak, előtörlesztés vállalása alapján dől el, hogy az adott hónapban ki juthat vásárlói joghoz, illetve arról a körülményröl sem, hogy a fogyasztó nem a szerződéskötéskor, hanem később, akár évek múltán juthat a vásárlási joghoz, s így a megszerezni kívánt dologhoz.

A fogyasztói csoport lényege, hogy a tagok rendszeres befizetései által összegyült megtakarításból egy sorsolás (vagy a szerződésben meghatározott többletfeltétel vállalásának) útján kiválasztott tag az általa előre meghatározott (ingó és ingatlan) dolog tulajdonjogának megszerzésére szerez lehetőséget. A GVH 17 fogyasztói csoportot szervező vállalkozás ellen folytatott le eljárást annak kifogásolásával, hogy nem vagy nem egyértelmúen adtak információt a fogyasztók részére a fogyasztói csoportok azon lényeges tulajdonságairól, amelyek alapján a fogyasztók számára egyértelműen érzékelhető lett volna, hogy nem hitelről vagy egyéb pénzügyi termékről van szó. A releváns információk (a vásárlói jog tartalma, megszerzésének bizonytalan időpontja, a kockázati tényező, a megszerezhető termékek jellege) hiányában a fogyasztók ugyanis feltételezhetően annak reményében kívántak szerződést kötni a fogyasztói csoport szervezőjével, hogy hamarosan pénzhez jutnak. A fogyasztói csoportokkal kapcsolatos kereskedelmi gyakorlatok kapcsán meghatározható két, a reklámokra fogékonyabb fogyasztói kör. Egyrészt a reklám külön megszólítja azt a fogyasztói réteget (BAR-listások, nyugdíjasok), akik valamilyen objektív oknál fogva (alacsony jövedelem, kezes hiánya) nem tudnak banki hitelt vagy egyéb pénzügyi terméket igénybe venni, ezért kiszolgáltatottabbak. Másrészről érintettek azok a hitelt felvenni szándékozó fogyasztók, akik összehasonlítva az említett kedvezőbb ajánlatot a bankok ajánlataival ez előbbi, vonzóbb alternatíva mellett döntenének (további információk hiányában ugyan, de racionálisan). A fogyasztói csoportokkal kapcsolatos gyakorlatok megítélésének alapját tehát a reprezentativitási heurisztika adta, hiszen a fogyasztó ügyleti döntését az azonnali, nem pedig a bizonytalan, akár 15 év múlva történő pénzhez jutás határozta meg, mivel a megtakarítás (mint jövőbeli fogyasztás) kevésbé fontos számukra, mint a jelenbeli fogyasztás, szükséglet kielégítése (Vj-132/2009). A vállalkozások hiányos szabályozási környezetre vonatkozó érvei, a számos elmarasztaló határozat és a hatóságokhoz, valamint civil szervezetekhez érkező több száz fogyasztói panasz hatására elsőként a fogyasztóvédelemről szóló törvény 2012. évi módosításával 2014. január 1-ig megtiltották újabb fogyasztói csoportok szervezését, majd 2014. január elsejével hatályba lépett a fogyasztói csoportokról szóló 530/2013. (XII.30.) Kormányrendelet, amely szigorú elöírásokat fogalmazott meg a 2012. január elsejét megelőzően létrehozott csoportokra vonatkozóan is és rendet teremtett ezen a problémás területen (lásd erről részletesebben Kőhidi 2014).

\section{Ellentmondásos esetek}

Vannak olyan esetek, amikor az eljárásba bevont vállalat is hivatkozik valamilyen gazdaságpszichológiai jelenségre. Ez történt az egyik gyorséttermi lánc esetében, ahol az egyes ételek (saláta, wrap, szendvics) nevében a ,grillcsirke” elnevezést vitatta a Versenytanács (Vj-016/2013). Úgy vélték, hogy a Versenytanács nem volt következetes abban, amikor figyelmen kívül hagyta a vizsgált kereskedelmi gyakorlat által érintett fogyasztók feltételezhető tudását és előzetes tapasztalatait a termékkel, illetve annak gyártójával kapcsolatosan, 
vagyis a keretezés és az összekapcsolási heurisztika szerepét. Az eljárás alá vont vállalkozás vitatta, hogy a fogyasztók a „grillcsirke” alatt kizárólag az egészben megsütött csirkét értik, különösen a társaság gyorséttermeit látogató fogyasztók körében, hiszen ott egészben sütött csirke sosem fordult elő. Nem állítható ugyanis álláspontja szerint, hogy az ésszerü fogyasztó a grillezett csirkehússal forgalmazott saláta, vagy szendvics esetén egészben megsütött grillcsirkére számítana. A kereskedelmi kommunikációban szereplő információk „csomagolása” alapján egyértelműen kiderülhetett a fogyasztók számára, hogy egy gyorsétterem termékéröl van szó, és mint ilyentől nyilvánvalóan nem várja, illetve várhatja el sem az otthoni, sem a hagyományos vendéglátásban jellemző ételeket és konyhatechnológiát. A Versenytanács ugyanakkor úgy vélte, hogy a termékek elnevezése és kommunikációja nem utalt arra, hogy húspogácsa formájában készült a termék és nem tisztán csirkehúsból, ezért a fogyasztók gyorséttermekre vonatkozó (alacsonyabb) elvárásaira való hivatkozást nem fogadta el.

A Vj-017/2013 számú eset kapcsán ugyanakkor épp a fogyasztók a vizsgált termékhez hasonló szolgáltatásokkal kapcsolatos tapasztalatait használta fel a Versenytanács hivatkozásként a vállalkozás által a „most” időhatározó alkalmazásával kapcsolatosan a hüségkártya használatával elérhető pénzvisszafizetés azonnaliságára vonatkozóan. A Versenytanács álláspontja szerint az azonnaliságra történő utalás azért is kifejezetten alkalmas arra, hogy megtévessze a fogyasztókat, mert a versenytársak közül soknál (például SuperShop, MOL Multipont kártya) valóban azonnal történik a kedvezmény (olyan kedvezmény, amely a vásárlást követően valóban azonnal felhasználható) jóváírása.

\section{KÖVETKEZTETÉSEK, ÖSSZEFOGLALÁS}

Az Fttv. törvény alapján hozott versenytanácsi határozatok közül három kiemelt témakörrel (a termékek eredet-megjelölésével, gyógy- és egészségre jótékony hatás-állitásokkal, valamint a fogyasztói csoportokkal) kapcsolatos esetpéldákat hoztunk fel. Mindhárom termékkört érintően azonosíthatóak voltak olyan döntéshozatali hibák kihasználását lehetővé tevő kereskedelmi gyakorlatok, különösen a termékek vásárlási döntés szempontjából fontos tulajdonságainak, ezzel kapcsolatos információk mennyiségére, átadási módjára és formájára vonatkozóan, amelyek során a vállalkozások részben az adott területre jellemző alul- vagy túlszabályozottsága miatt megfelelési törekvéseik ellenére sem tudtak megfelelő körültekintéssel eljárni.

$\mathrm{Az}$ eredet-megjelöléssel és a fogyasztói csoportokkal kapcsolatos esetek nagy számára való tekintettel jogszabályi rendelkezés született a terület átfogóbb és hatékonyabb szabályozására, amely egyrészt figyelembe veszi és támogatja a fogyasztók döntéshozatali mechanizmusait, másrészt a vállalkozások számára is tudatosabb megfelelést tesz lehetővé. Ez a gyógy- és egészségre jótékony hatás-állításokra vonatkozóan még várat magára, véleményünk szerint azonban ezen a területen is lépésre van szükség, különösen, hogy ezen gyakorlatok célcsoportja jellemzően a kiszolgáltatott fogyasztói kör (idősek, betegek).

A bemutatott esetek is felhívják a figyelmet arra, hogy a fogyasztóvédelmi szabályozás témaköre lényeges a marketingoktatásban és a gyakorlatban, hiszen fontos, hogy a gyakorlati szakemberek tisztában legyenek a fogyasztóvédelmi szabályozással. 


\section{HIVATKOZÁSOK}

Balogh V. (2010), ,A fogyasztókkal szembeni tisztességtelen kereskedelmi gyakorlat tilalmáról szóló 2008. évi XLVII. törvény”, In: Pázmándi K. (szerk.) - Kaszainé Mezey K. - Zavodnyik J. - Balogh V.: Magyar fogyasztóvédelmi és reklámjog. HVG-ORAC, Budapest, 99-218

Bernoulli, D. (1954 [1738]), "Exposition of a New Theory on the Measurement of Risk", Econometrica, 22 1, 23-36 DOI: https://doi. org/10.2307/1909829

Camerer, C., Issacharoff, S., Loewenstein, G., O'Donoghue, T. and Rabin, M. (2003), "Regulation for Conservatives: Behavioral Economics and the Case for 'Asymmetric Paternalism"', University of Pennsylvania Law Review, 151 1211-54 DOI: https://doi.org/10.2307/3312889

Fekete O. (2006), „A versenyjog szerepe a fogyasztóvédelemben", COMITATUS, 16 10, 32-42

Fletcher, A. (2008), "What Do Policy-Makers Need from Behavioural Economics? How Can Behavioural Economics Improve Policies Affecting Consumers?", DG SANCO Conference, 28th November 2008, Brussels

GVH (2009), A fogyasztói döntések szabadságára vonatkozó, a GVH által követett alapelvek 2009, Gazdasági Versenyhivatal, http://www. gvh.hu/data/cms 1022582/11695FFBAC14C71 AC.pdf Letöltés: 2011.05.03.

GVH (2012), „Magyar termék” megjelölés miatt inditott GVH fellépések ismertsége a lakosság körében, Gazdasági Versenyhivatal, http://www.gvh.hu/akadalymentes//data/ cms 1000345/Scale_\%C3\%9Cgyismeret_magyar_term\%C3\%A9k_tanulm $\% \mathrm{C} 3 \% \mathrm{~A} 1$ ny_honlapra.pdf Letöltés: 2012.05.10.

Hámori B. (2003), „Kísérletek és kilátások. Daniel Kahneman”, Közgazdasági Szemle, L Szeptember, 779-99

Kahneman, D. (2013), Gyors és lassú gondolkodás. HVG Kiadó, Budapest

Kahneman, D. and Tversky, A. (1979), "Prospect Theory: An Analysis of Decision under Risk", Econometrica, 47 2, 263-92 DOI: https://doi. org/10.2307/1914185

Koltay G. - Vincze J. (2009), „Fogyasztói döntések a viselkedési közgazdaságtan szemszögéből”, Közgazdasági Szemle, LVI 495-525

Kőhidi Á. (2014), „A fogyasztói csoportok jogi szabályozása és a kapcsolódó szerződések érvénytelensége", Gazdaság és jog, 22 2, 8-13

Larrick, R. P. and Soll, J. B. (2008), „The MPG Illusion", Science, 320 1593-4 DOI: https://doi. org/10.1126/science. 1154983

Malota E. (2011), „Magyar termék - hazai fogyasztó", Fogyasztóvédelmi Szemle, V 2, 13-20

Miskolczi Bodnár P. (2011), „Termékek „magyarként" való reklámozásának jogi kérdései”, Versenytükör, VII 2, 25-35

Neumann, J. and Morgenstern, O. (1947), Theory of Games and Economic Behavior. Princeton University Press, Princeton

OECD (2017), "Use of Behavioural Insights in Consumer Policy", OECD Science, Technology and Industry Policy Papers, No. 36, OECD Publishing, Paris DOI: https://doi.org/10.1787/ c2203c35-en

Ottlakán J. (2012), „Az egészségre ható és gyógyhatás állítások a Gazdasági Versenyhivatal gyakorlatának tükrében", Fogyasztóvédelmi Szemle, VI 1

Süle M. (2017), „Marketingkommunikációs eszközök fogyasztóvédelmi megítélése a tisztességtelen kereskedelmi gyakorlatok tükrében", Marketing és Menedzsment, LI 4, 15-25

Thaler, R. H. and Sunstein, R. C. (2011 [2008]), Nudge. Jobb döntések egészségről, pénzről és boldogságról - a pénzügyi válság után. Manager Könyvkiadó, Budapest

van Bavel, R., Herrmann, B., Esposito, G. and Proestakis, A. (2013), JRC Scientific and Policy Reports - Applying Behavioural Sciences to EU Policy-making, European Commission, http://ec.europa.eu/dgs/health_consumer/information_sources/docs/30092013 jrc_scientific_ policy_report_en.pdf Letöltés: 2015. 01.13. 
Berki-Süle Margit PhD, adjunktus sule@erg.bme.hu

Budapesti Müszaki és Gazdaságtudományi Egyetem

Gazdaság- és Társadalomtudományi Kar

Ergonómia és Pszichológia Tanszék

Hlédik Erika PhD, adjunktus hledik@gti.elte.hu

Eötvös Loránd Tudományegyetem

Gazdálkodástudományi Intézet Érveléselmélet és Marketing Tanszék

\section{Behavioural Economics in Consumer Protection}

\section{THE AIMS OF THE PAPER}

Revealing unfair manipulation of consumer decisions and the related consumer protection regulations are important for understanding consumer behaviour. In the last decades, research findings of behavioural economics play a key role in shaping consumer policy. In our paper, we examine how results of behavioural economics could be applied in the practice of consumer protection.

\section{METHODOLOGY}

Based on case studies from the decisions of the Hungarian Competition Authority (GVH) connected to three types of products, we present examples of decision-making heuristics and look at how authorities resolved these practices and how they affected regulations.

\section{MOST IMPORTANT RESULTS}

We identified commercial practices taking advantage of decision-making mistakes (even if unintentionally), particularly in terms of quantity, delivery method and product attributes relevant in buying decision making process. In part, this might be traced back to the over- or under-regulation associated with certain groups of products.

\section{RECOMMANDATIONS}

The non-rational consumer behaviour patterns explored by behavioural economics both implicitly and explicitly appear in consumer protection legislation and practices. Therefore, they may serve as a solid basis not only for law enforcement but for legislation as well. We also aim to highlight the importance of consumer protection regulation studies in marketing education. In addition, we argue that the analysis of our cases could be useful for marketing professionals. Profound knowledge of regulation is a key aspect for the corporate side, and consumer protection helps to make better decisions on the demand side.

Keywords: behavioural economics, consumer decision making process, consumer protection, unfair commercial practices 